\title{
Should EU cross-border cooperation programmes focus mainly on reducing border obstacles?*
}

\section{Eduardo Medeiros}

Instituto Universitário de Lisboa (ISCTE-IUL), DINÂMIA'CET-IUL

eduardo.medeiros@iscte-iul.pt

Reception: January 2018

Acceptance: March 2018

Publication: July 2018

\begin{abstract}
EU cross-border cooperation programmes were formally established with the launching of the first INTERREG Community Initiative (1989-1993). Since then, these programmes have been expanding to Northern and Eastern Europe. At present, the INTERREG V-A (2014-2020), formally known as European Territorial Cooperation (strand A - crossborder cooperation), covers more than $60 \%$ of the EU territory and $40 \%$ of EU inhabitants, making it one of the most politically relevant EU financed programmes. For the most part, however, these programmes are still regarded by both the European Commission and national and regional authorities as a complementary financial tool to support growth and regional development strategies. In this context, this article analyses what have been the main strategic goals of the EU cross-border cooperation programmes, whilst supporting a new strategic paradigm for these programmes during the post-2020 EU policies programming phase focused on reducing the barrier-effects in all their main dimensions.

Keywords: Cross-border cooperation; barrier-effects; border obstacles; EU Cohesion Policy; INTERREG; European Territorial Cooperation
\end{abstract}

Resum. Haurien els programes de cooperació transfronterera de la UE de centrar-se principalment en la reducció dels obstacles fronterers?

Els programes de cooperació transfronterera de la UE es van establir formalment amb el llançament de la primera iniciativa INTERREG (1989-1993). Des de llavors, aquests programes s'han estès al nord i l'est d'Europa. Fins ara, el programa INTERREG V-A (2014-

* This paper is part of the ongoing research project "Cooperación Transfronteriza en Europa, una geopolítica de escala local. Análisis en cinco países europeos de buenas prácticas para la integración y el desarrollo global" (TRANSBORDEURCOP). CSO2015-67124-R (MINECO/FEDER, UE). 
2020), conegut formalment com a Cooperació Territorial Europea (Eix A - cooperació transfronterera), cobreix més del 60\% del territori de la UE i el $40 \%$ dels seus habitants, la qual cosa en fa un dels programes polítics finançats més rellevants de la UE. Tanmateix, tant per a la Comissió Europea com per a les autoritats nacionals, aquests programes encara són vistos en bona part com un instrument financer complementari per donar suport al creixement i a les estratègies de desenvolupament regional. En aquest context, el present article analitza quins han estat els principals objectius estratègics dels programes de cooperació transfronterera de la UE. Al mateix temps, dona suport a un nou paradigma estratègic per a aquests programes en la fase programàtica post-2020, enfocat a reduir els efectes barrera en totes les dimensions.

Paraules clau: cooperació transfronterera; efectes-barrera; obstacles fronterers; política de cohesió de la UE, INTERREG; cooperació territorial europea

Resumen ¿Deberían los programas de cooperación transfronteriza de la UE centrarse principalmente en reducir los obstáculos fronterizos?

Los programas de cooperación transfronteriza de la UE se establecieron formalmente con el lanzamiento de la primera iniciativa INTERREG (1989-1993). Desde entonces, estos programas se han extendido al norte y este de Europa. Hasta ahora, el programa INTERREG V-A (2014-2020), conocido formalmente como Cooperación Territorial Europea (Eje A - cooperación transfronteriza), cubre más del 60\% del territorio de la UE y el $40 \%$ de sus habitantes, lo que hace que este sea uno de los programas políticos financiados más relevantes de la UE. Sin embargo, tanto para la Comisión Europea como para las autoridades nacionales, estos programas son en gran parte vistos como un instrumento financiero para complementar y apoyar el crecimiento y las estrategias de desarrollo regional. En este contexto, el presente artículo analiza cuáles han sido los principales objetivos estratégicos de los programas de cooperación transfronteriza de la UE. Al mismo tiempo, apoya un nuevo paradigma estratégico para estos programas en su fase programática post-2020, enfocado a reducir los efectos barrera en todas sus dimensiones.

Palabras clave: cooperación transfronteriza; efectos-barrera; obstáculos fronterizos; política de cohesión de la UE; INTERREG; Cooperación Territorial Europea

Résumé. Les programmes de coopération transfrontalière de l'UE devraient-ils viser principalement à réduire les obstacles frontaliers?

Les programmes de coopération transfrontalière de l'UE ont été formellement établis avec le lancement de la première initiative INTERREG (1989-1993). Depuis lors, ces programmes se sont étendus au nord et à l'est de l'Europe. Jusqu'à présent, le programme INTERREG V-A (2014-2020), connu officiellement comme Coopération Territoriale Européenne (Axe A - La coopération transfrontalière), couvre plus de 60\% du territoire de l'UE et $40 \%$ de ses habitants, ce qui en fait un des programmes politiques financés par l'UE les plus remarquables. Néanmoins, pour la Commission européenne ainsi que pour les autorités nationales, ces programmes sont principalement considérés comme un instrument financier complémentaire pour soutenir les stratégies de croissance et de développement régional. Dans ce contexte, cet article analyse les principaux objectifs stratégiques des programmes de coopération transfrontalière de l'UE. En même temps, il soutient un nouveau paradigme stratégique pour ces programmes dans leur phase programmatique post-2020, axée sur la réduction des effets barrière dans toutes leurs dimensions.

Mots-clés: coopération transfrontalière; effets-barrière; obstacles frontaliers; politique de cohésion de l'UE; INTERREG; coopération territoriale européenne 


\section{Summary}

\begin{tabular}{|c|c|}
\hline \multirow{3}{*}{$\begin{array}{r}1 . \text { Introduction } \\
\text { 2. The main goals of cross-border } \\
\text { cooperation programmes in Europe: } \\
\text { a historical perspective }\end{array}$} & \multirow{2}{*}{$\begin{array}{l}\text { 5. INTERREG potentials and } \\
\text { limits to reducing border barriers } \\
\text { in a nutshell }\end{array}$} \\
\hline & \\
\hline & 6. Conclusion \\
\hline \multirow{2}{*}{$\begin{array}{l}\text { 3. Persisting border obstacles } \\
\text { and barrier-effects in Europe }\end{array}$} & Acknowledgements \\
\hline & Bibliographical references \\
\hline $\begin{array}{l}\text { 4. Placing the reduction of border } \\
\text { obstacles at the core of cross-border } \\
\text { cooperation programmes }\end{array}$ & \\
\hline
\end{tabular}

\section{Introduction}

European Territorial Cooperation (ETC) is a relatively recent policy process (Wassemberg, 2015), as it only became one of the major goals of the European Union (EU) Cohesion Policy by 2007. This process basically includes three distinct types of cooperation: (i) cross-border cooperation (CBC); (ii) transnational cooperation; and (iii) interregional cooperation. The first (CBC), however, has been formally forged in Europe since the mid-1950s in border areas separating 'old EU Member States' (France, Luxemburg, Germany, the Netherlands and Belgium), and the Nordic countries (Sweden, Denmark, Norway and Finland) (AEBR, 2008; Medeiros, 2010, 2011; Perkmann, 2003).

In 1989, the European Commission (EC) started to grant support for $\mathrm{CBC}$ projects designed to tackle structural development difficulties of EU border areas. One year later, the iconic INTERREG Community Initiative was created with the intention to prepare EU border areas for the implementation of the Single Market (EC, 2007). Since then, the INTERREG, now known as ETC, has suffered several metamorphoses in adapting to mainstream EU development agendas (Lisbon and Gothenburg Agendas and EUROPE 2020). As a consequence, the goals of EU CBC programmes have changed overtime, while covering a wide spectrum of policy goals and themes.

Indeed, border areas have a multidimensional reality, as they involve a plethora of interrelated aspects, such as all sorts of natural and artificial barriers, as well as cultural, social, economic and political interactions. In the face of this reality, a significant number of border regions' territorial development goals can only be solved efficiently by means of efficient CBC processes (EC, 1999), which calls for continued networking, cooperation and integration between various entities (EC, 2011: 4). Hence, the study of borders has become reinvigorated in the last few decades (Newman, 2006: 172), while engaging EU internal borders and EU neighbour countries as well (Gaubert and Yann, 2010).

Territorial cooperation processes, and notably CBC ones, are also seen as vital pillars to supporting territorial cohesion policies (Medeiros, 2014c, 2016a, 
2016b). As the Green Paper on Territorial Cohesion highlights, territorial cooperation aims at overcoming division. More pointedly, it alerts to the fact that 'problems of connectivity and concentration can only be effectively addressed with strong cooperation at various levels' (EC, 2008: 7). These problems can have a day-to-day and face-to-face character associated with social contacts, commuter flows and business relationships (Perkmann, 2007a: 258). On the other hand, they might have a longer-term character related, for instance, to supporting local/regional strategies to become global (Johnson, 2009: 177), or to supporting institutional building (Medeiros, 2013) or cross-border planning activities (Decoville et al., 2013; Medeiros, 2014b, 2014d).

More importantly, however, is the realisation that $\mathrm{CBC}$ commonly attracts motivated and determined stakeholders aiming to develop expertise and networks (Lawrence, 2011: 370). Running parallel to this, cross-border entities, such as Euroregions (Brenner, 2000), aim to establish themselves as key regional players (Perkmann, 2007b: 867). As a result, EU CBC programmes have been 'instrumental to ensure that national borders do not form barriers to balanced development and integration of the European territory' (ESPON, 2007: 3), even though some of them have yet to be implemented with a genuine cross-border nature (EP, 1996: 12).

Being profoundly preconditioned by EU Cohesion Policy regulations, EU $\mathrm{CBC}$ programmes have frequently shifted away from the goal of reducing persisting border barriers, at least in a direct mode. Such a stance led us to provide a cursory glance on the evolution of the main goals of EU CBC programmes since 1990 until the present (2017) in the first section of this article. The following section will then discuss the most persisting border obstacles in Europe based on the available literature and recent EU surveys. Finally, a third section elaborates on a policy vision to place the reduction of border obstacles at the core of post-2020 CBC programmes.

\section{The main goals of cross-border cooperation programmes in Europe: a historical perspective}

It goes without saying that, after 60 years of formal $\mathrm{CBC}$ experiences between some 'old' border regions in Europe, and at least 10 years between eastern European border regions, CBC is solidly established in Europe. Curiously, even in EU regions with modest economic potential this process is well advanced (ESPON ATLAS, 2014: 98). This reality, in which EU CBC entities and processes have grown exponentially since the 1990s (Harguindéguy, 2007; Perkmann, 1999) results, in large measure, from the available funding from the INTERREG/ETC programmes. In this light, the policy intervention priorities defined for these programmes have greatly determined their broader thematic intervention.

Indeed, a closer look at the evolution of both the main goals and thematic priorities defined at each INTERREG/ETC-A programming period reveals this broad and disperse pattern of territorial development investment (Table 1). This 
Table 1. Main goals and priorities of the INTERREG-A programmes (1989-2020)

\begin{tabular}{|c|c|c|}
\hline INTERREG-A & Main Goal & Financed policy priorities \\
\hline I. $1989-1993$ & $\begin{array}{l}\text { Prepare the border areas for the } \\
\text { opening of the Single Market, with } \\
\text { an eye to economic and social } \\
\text { cohesion (EC, 1990a) }\end{array}$ & $\begin{array}{l}\text { - Aid to SMEs } \\
\text { - Tourism and culture } \\
\text { - Energy supply } \\
\text { - Rural development and commerce } \\
\text { - Education and training } \\
\text { - Protection of environment } \\
\text { - Water supply and waste disposal } \\
\text { - Accessibilities infrastructure } \\
\text { - Spatial planning }\end{array}$ \\
\hline II. 1994-1999 & $\begin{array}{l}\text { Develop cross-border social and } \\
\text { economic centres through common } \\
\text { development strategies (EC, 2017a) }\end{array}$ & $\begin{array}{l}\text { - Aid to SMEs } \\
\text { - Tourism and culture } \\
\text { - Energy supply } \\
\text { - Rural development and commerce } \\
\text { - Education and training } \\
\text { - Employment and mobility } \\
\text { - Health } \\
\text { - Protection of environment } \\
\text { - Water supply and waste disposal } \\
\text { - Better public administration } \\
\text { - Accessibilities infrastructure } \\
\text { - Information and communication } \\
\text { - Spatial planning }\end{array}$ \\
\hline III. 2000-2006 & $\begin{array}{l}\text { Develop cross-border economic and } \\
\text { social centres through joint strategies for } \\
\text { sustainable territorial development (EC, } \\
2017 \mathrm{~b} \text { ) }\end{array}$ & $\begin{array}{l}\text { - Aid to SMEs } \\
\text { - Rural development } \\
\text { - Urban and coastal development } \\
\text { - Education and training } \\
\text { - Culture } \\
\text { - Employment and mobility } \\
\text { - Health } \\
\text { - Protection of environment } \\
\text { - Energy efficiency and renewable energy } \\
\text { - Better public administration } \\
\text { - Legal systems } \\
\text { - Information and communication } \\
\text { - Transport }\end{array}$ \\
\hline IV. 2007-2013 & $\begin{array}{l}\text { Reduce the negative effects of borders } \\
\text { such as administrative, legal and physical } \\
\text { barriers; tackle common problems and } \\
\text { exploit untapped potential. Through } \\
\text { joint management of programmes and } \\
\text { projects, mutual trust and understanding } \\
\text { are strengthened and the cooperation } \\
\text { process is enhanced (EC, 2017c) }\end{array}$ & $\begin{array}{l}\text { - Entrepreneurship } \\
\text { - Education and training } \\
\text { - Employment and mobility } \\
\text { - Equal opportunities } \\
\text { - Management of natural resources } \\
\text { - Information and communication } \\
\text { - Transport } \\
\text { - Link between rural and urban areas } \\
\text { - Joint use of infrastructure }\end{array}$ \\
\hline V. $2014-2020$ & $\begin{array}{l}\text { Tackle common challenges identified } \\
\text { jointly in the border regions and exploit the } \\
\text { untapped growth potential in border areas, } \\
\text { while enhancing the cooperation process } \\
\text { for the purposes of the overall harmonious } \\
\text { development of the Union (EC, } 2017 \mathrm{~d} \text { ) }\end{array}$ & $\begin{array}{l}\text { - Aid to SMEs } \\
\text { - Research and innovation } \\
\text { - Education and training } \\
\text { - Employment and mobility } \\
\text { - Social inclusion } \\
\text { - Low carbon economy } \\
\text { - Combating climate change } \\
\text { - Environment and resource efficiency } \\
\text { - Sustainable transport } \\
\text { - Better public administration } \\
\text { - Information and communication }\end{array}$ \\
\hline
\end{tabular}

Source: own elaboration. 
follows from a prevailing and common understanding in which CBC programmes are an additional source of revenue to promote the regional development of EU border areas. By implication, what initially was designed to help prepare border areas for the opening of the EU Single Market, as well as promoting administrative collaboration and reducing their isolation within the EU territory (EC, 1990a, 1990b), has gradually shifted into a socio-economic support tool for EU internal and external border areas.

Indeed, cross-border cooperation processes between EU and non-EU countries, such as Norway and Switzerland, has been in the making since the mid1990s. Also noteworthy is the different character presented by each EU CBC programme, as each is specifically adapted to particular border regions' idiosyncrasies. Moreover, the degree of genuine versus reduced cross-border collaboration intensity varies across EU CBC programmes, whilst some present an interregional dimension rather than a mere cross-border character. This is a result of the lack of influential cross-border cities (based on the border NUTS III). Here, the EC has proposed a $30 \mathrm{~km}$ buffer zone to define the EU border areas. However, the lack of available indicators for such areas justifies the maintenance of the NUTS III criteria for the delimitation of EU CBC programmes.

In view of the above, the implementation of EU CBC programmes has given concrete support to fomenting business partnerships between small and medium enterprises (SMEs) and research centres, to improving border physical accessibilities (EC, 2014; Medeiros, 2014a) and cross-border entrepreneurship processes (Smallbone and Welter, 2012: 38). In addition, these programmes have supported political cooperation and partnership-based cooperation between small and medium-sized towns, while bringing several authorities at different levels to tackle all sorts of border issues. Furthermore, these programmes have been: (i) promoting knowledge and experiences exchange; (ii) developing strategic planning capabilities; (iii) minimising negative externalities; (iv) improving joint management of natural resources; (v) improving access to transport and communication networks; (vi) developing joint use of infrastructure; (vii) supporting links between urban and rural areas; (viii) promoting administrative capacity, employment and equal opportunities; (ix) developing multilinguism; (x) supporting research and innovation; (xi) aiding professional mobility and (xii) supporting spatial planning (Chilla et al., 2012; Territorial Agenda, 2007: 8).

Curiously, from a policy main strategic goal, the reduction of the negative border effects was only present in the fourth INTERREG/ETC programming period (2007-2013). More worrying still was the adoption by ETC programmes of the 11 thematic goals defined for the 2014-2020 EU Cohesion Policy phase, as they are not specifically tailor-made (Barca, 2009) for solving cross-border issues. This prompts us to confront the design of current interventions for EU CBC programmes. By way of illustration, the analysis of the EU INTERREG project database ${ }^{1}$ shows that, since 2000,

1. <https://www.keep.eu/keep/>. 
Table 2. Main thematic issues in the EU CBC Programmes (2000-2013)

\begin{tabular}{|c|c|c|}
\hline Themes & No. projects & $\%$ \\
\hline 1. Accessibilities & 831 & 3.06 \\
\hline Improving transport connections & 346 & 1.27 \\
\hline Multimodal transport & 74 & 0.27 \\
\hline Transport and mobility & 411 & 1.51 \\
\hline 2. Social/Culture & 7321 & 26.96 \\
\hline Community integration and common identity & 1074 & 3.96 \\
\hline Cultural heritage and arts & 2570 & 9.46 \\
\hline Demographic change and immigration & 150 & 0.55 \\
\hline Education and training & 2183 & 8.04 \\
\hline Health and social services & 735 & 2.71 \\
\hline Social inclusion and equal opportunities & 609 & 2.24 \\
\hline 3. Economy/Technology & 11218 & 41.31 \\
\hline Agriculture and fisheries and forestry & 878 & 3.23 \\
\hline Clustering and economic cooperation & 992 & 3.65 \\
\hline Coastal management and maritime issues & 337 & 1.24 \\
\hline Construction and renovation & 350 & 1.29 \\
\hline ICT and digital society & 742 & 2.73 \\
\hline Infrastructure & 789 & 2.91 \\
\hline Innovation capacity and awareness-raising & 366 & 1.35 \\
\hline Knowledge and technology transfer & 743 & 2.74 \\
\hline Labour market and employment & 629 & 2.32 \\
\hline Logistics and freight transport & 121 & 0.45 \\
\hline New products and services & 457 & 1.68 \\
\hline Rural and peripheral development & 271 & 1.00 \\
\hline Scientific cooperation & 562 & 2.07 \\
\hline SME and entrepreneurship & 1038 & 3.82 \\
\hline Tourism & 2750 & 10.13 \\
\hline Traditional energy & 16 & 0.06 \\
\hline Urban development & 177 & 0.65 \\
\hline 4. Institutional/Administrative & 3524 & 12.98 \\
\hline Cooperation between emergency services & 292 & 1.08 \\
\hline Governance, partnership & 408 & 1.50 \\
\hline Institutional cooperation and cooperation networks & 2104 & 7.75 \\
\hline Regional planning and development & 572 & 2.11 \\
\hline Safety & 148 & 0.55 \\
\hline 5. Environment & 3754 & 13.83 \\
\hline Climate change and biodiversity & 545 & 2.01 \\
\hline Energy efficiency & 224 & 0.82 \\
\hline Green technologies & 218 & 0.80 \\
\hline Managing natural and man-made threats, risk management & 451 & 1.66 \\
\hline Renewable energy & 311 & 1.15 \\
\hline Soil and air quality & 82 & 0.30 \\
\hline Sustainable management of natural resources & 1026 & 3.78 \\
\hline Waste and pollution & 264 & 0.97 \\
\hline Water management & 336 & 1.24 \\
\hline Waterways, lakes and rivers & 297 & 1.09 \\
\hline Others & 505 & 1.86 \\
\hline Evaluation systems and results & 505 & 1.86 \\
\hline
\end{tabular}

Source: own elaboration based on KEEP database. 
most approved projects have supported economic (41\%) and social (27\%) development processes on EU border regions, whilst stepping up environmental (14\%) and institutional (13\%) development as well (Table 2). To make things clear, we do not see as a negative thing the support given to promoting regional development of EU border regions from CBC programmes. We propose, however, that the bulk of this support be placed in projects which directly and indirectly contribute to reducing all sorts of prevailing border obstacles in the EU territory, which we will analyse in depth in the following section.

\section{Persisting border obstacles and barrier-effects in Europe}

Over the course of the last three decades, the INTERREG/ETC programmes have made a crucial contribution to stimulating territorial development and reducing all sorts of border barriers in EU border regions (EC, 2010; LRDP, 2003; Medeiros, 2010, 2015, 2017a; Wassemberg et al., 2015). Despite these efforts, the presence of national administrative borders creates inevitable constraints to citizens who cross EU borders. Recent EU surveys on persistent border obstacles confirm awareness of this. More specifically, they conclude that legal-administrative and language-related barriers are on the top of EU citizens' concerns when crossing EU borders (EC, 2016) (Figure 1).

Figure 1. Persisting border obstacles in Europe from EU surveys (\%)

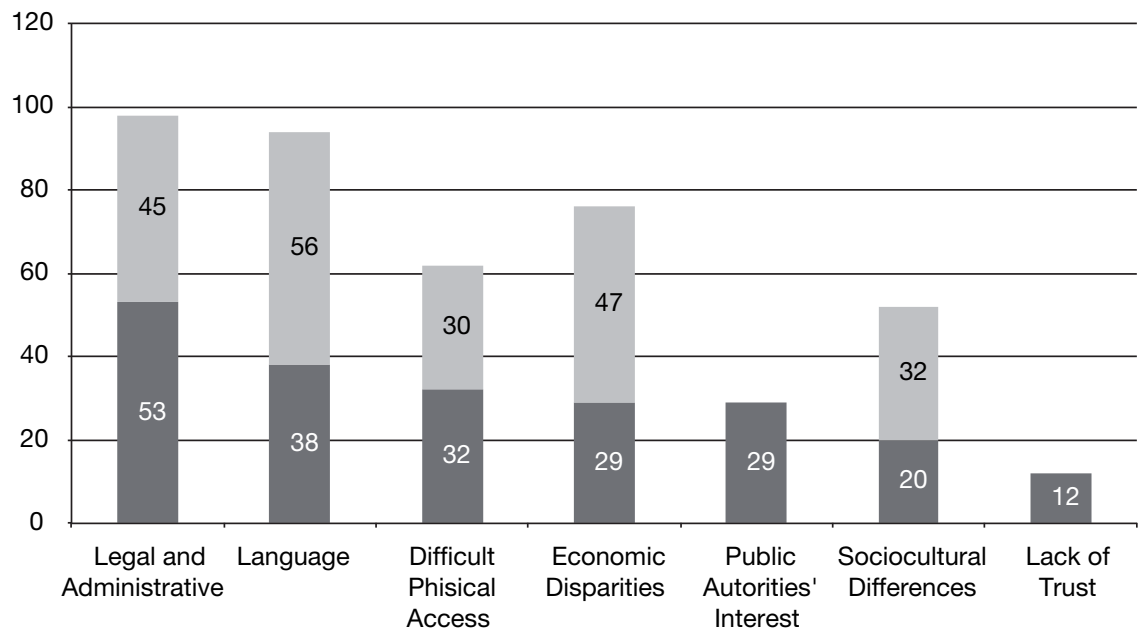

DG REGIO Public Consultation on overcoming obstacles in border regions

Eurobarometer on border obstacles - 2015

Source: own elaboration. 
Figure 2. Most important obstacles according to Eurobarometer survey 2015

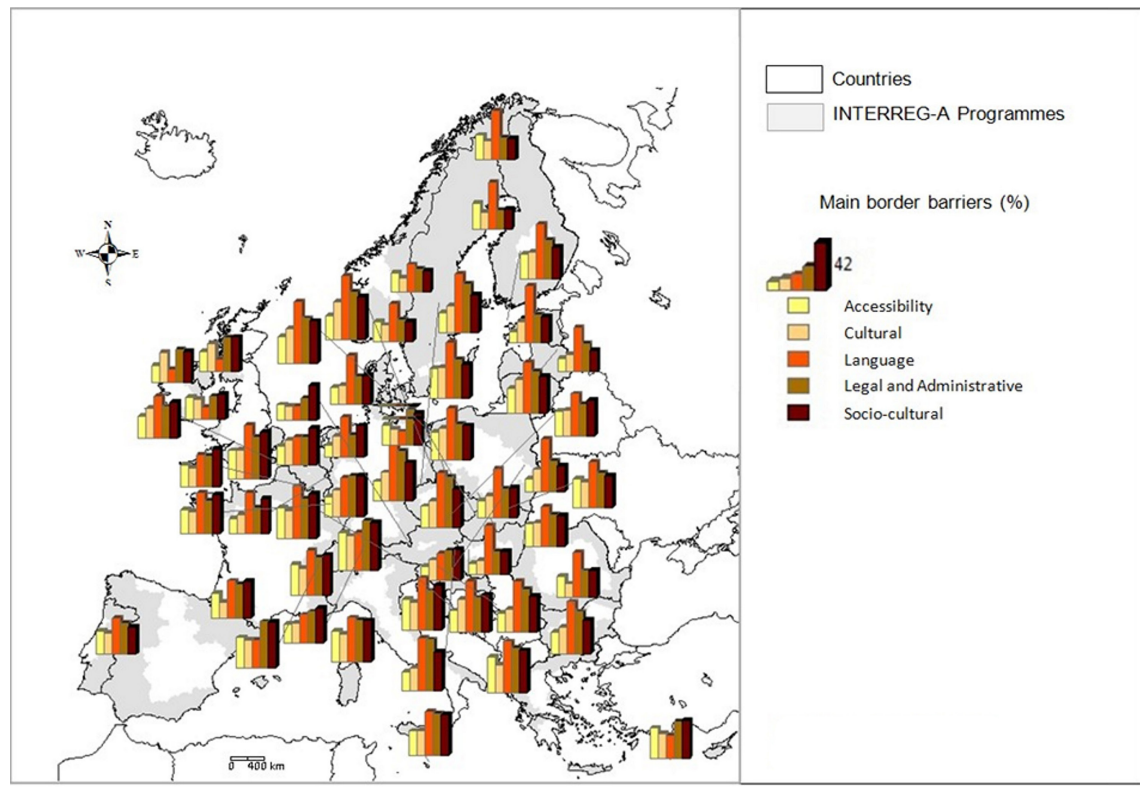

Source: own elaboration based on Eurobarometer 2015.

As expected, these results vary from Member State to Member State (Figure 2). For instance, the language barrier is quite strong in several border regions (e.g. Finland-Sweden, Greece-Bulgaria), and relatively weak in others (e.g. Austria-Germany, Ireland-UK). More to the point, and according to Lundén (2004: 101), at least six different cases of the linguistic boundary situation can be discerned in Europe:

1. Language is the same on both sides and is official in both countries (e.g. Austria and Germany);

2. Language is the same, but on one side it has a lower status, either a so-called wild dialect without proper teaching in school, etc., or it is a weak minority language (e.g. Finland-Sweden in the north, France-Germany);

3. Language is the same, but on one side it is not recognised as a state language;

4. Languages are officially different but mutually intelligible (e.g. NorwaySweden, Belarus-Ukraine);

5. Languages are both officially different and mutually unintelligible (e.g. Czech Republic-Germany, Austria-Hungary);

6. Official languages are different, mutually unintelligible, but along both sides of the border there is a third language group; Part of the boundaries between Estonia-Latvia (Russian) and France-Spain (Basque, Provençal and Catalan). 
Figure 3. Prevailing border obstacles in European Borders according to EU citizens - 2016

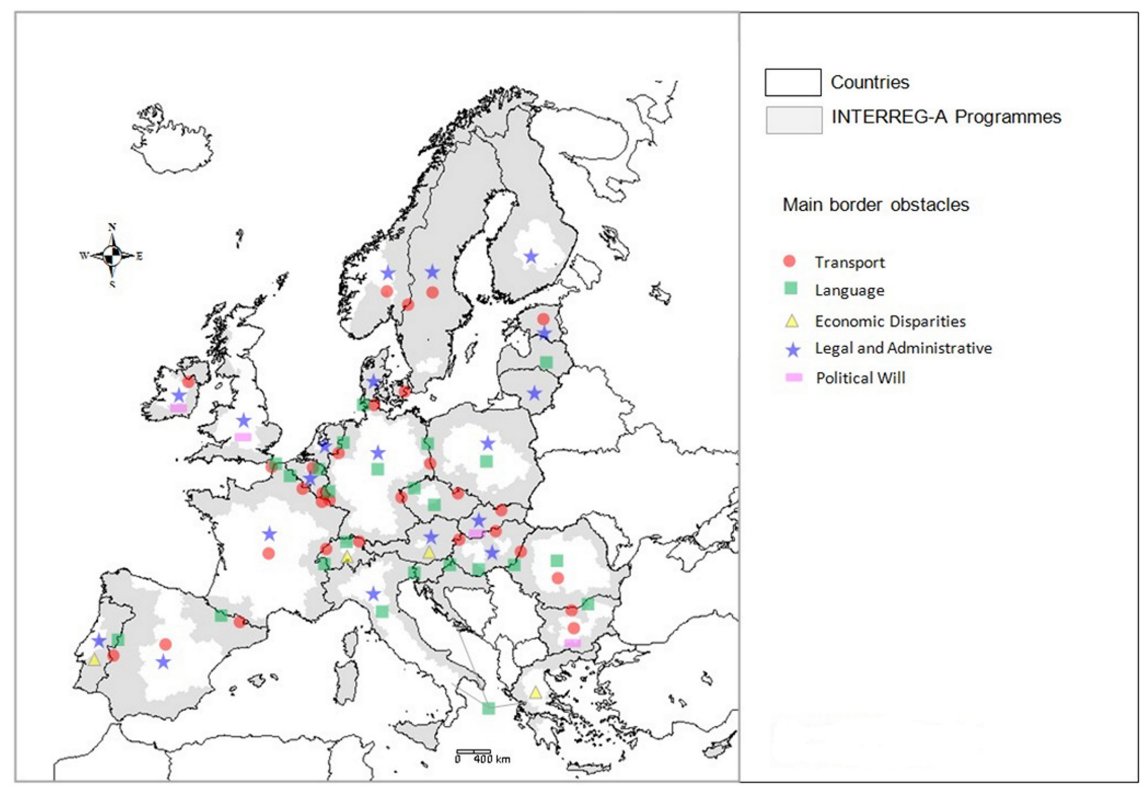

Source: EC (2016), Medeiros (2016c) - own elaboration.

'In boundary areas there are usually many polyglots. The individual repertoire (the linguistic domain a certain speaker will master) can be different for the various languages spoken or understood. As mentioned above, the attitude towards different languages in the border area may differ according to social class, religion and ethnic allegiance' (Lundén, 2004: 101).

In much the same way, and even more intensively, legal and administrative barriers place enormous restraints on EU citizens, mainly in three distinct domains: (i) access to employment; (ii) access and use of social security, pension and taxation systems; and (iii) lack of recognition of education and qualifications (EC, 2016). Again, such types of obstacles are especially relevant in open borders, where cross-border commuting is higher, as is the case of border areas between EU 'old Member States' (Figure 3). That does not mean these legal and administrative types of obstacles are not present in the remaining EU border areas. However, local border citizens perceive these obstacles to be much lower because cross-border commuting intensity levels are much lower.

On a positive note, however, cross-border commuting and migration related issues 'are becoming increasingly relevant from both an analytical as well as a policy perspective' (Huber and Nowotny, 2013: 1463). At a more general level, current research concludes that cross-border commuting is still at a low level in Europe, when compared with the intra-national commuting volumes (Buch et al., 2009). The variation in these volumes depends on a number 
of different factors. As a recent study asserts 'while working in a neighbouring country may be the result of a choice forced by high unemployment in the domestic market and a need for labour on the other side of the border, this decision may also stem from other motives such as workers calculating the opportunity offered by cross-border commuting: wage differentials, attractive social benefits tax optimisation, lower cost of land and property, etc.' (MOT, 2015: 66).

A crucial factor affecting cross-border commuting is the availability, quality and capacity of cross-border physical accessibilities. In this regard, EU transport policies, together with EU Cohesion Policies, have significantly contributed to improving EU transnational accessibility, both by road and rail (EC, 2014; Molle, 2007). Nevertheless, 'the analysis of the impacts of the development of the trans-European high-speed rail network confirms the view that TENs, in contrast to the claims of the Maastricht Treaty, may widen rather than narrow differences in accessibility between central and peripheral regions' (Vickerman et al., 1999: 12).

The positive effects of the improvements of the European road system over the last decades and its direct positive impact in improving the levels of productivity are, however, not questionable (Matas et al., 2015). On the other hand, this constant improvement in accessibility levels has produced positive spillover effects in EU border areas (López et al., 2009). Crucially, cross-border public transport represents another important factor of the European integration process, and in the improvement of physical crossborder accessibility, as they have the potential to encourage the mobility of cross-border workers, and permit the multiplication of cross-border exchanges and contacts. However, the present supply of cross-border public transport is still quite reduced in view of the European cross-border commuting needs (MOT, 2006: 3).

On closer scrutiny, the deep analysis of the responses from the 2016 DG REGIO border obstacles survey also demonstrates that the lack of availability of public transport is considered as one of the most important barriers to crossborder commuting by EU citizens (Table 3). Furthermore, existing tariffs are seen as excessive and scheduled information is rarely sufficient. Moreover, the frequency of available cross-border transport services is also reduced in many EU border areas, whilst the harmonisation of ticket rules and systems is for the most part lacking (Medeiros, 2016c).

A more recent (2017) collection of the EU border obstacles database also reveals that their intensity and perception varies across Europe, being wider in its western half. Curiously, the word map constructed around this database places the word 'transport' in a quite relevant position amongst the main concerns associated with crossing EU borders by EU citizens (Figures 4 and 5). 
Table 3. Identification of main border obstacles in Europe by barrier effect dimension (2016)

\begin{tabular}{|c|c|c|}
\hline Barrier Effect Dimension & $\mathrm{N}^{\circ}$ & (\%) \\
\hline 1. Accessibilities & 292 & 23.76 \\
\hline 1.1. Public transport & 110 & 8.95 \\
\hline 1.2. Rail connections & 37 & 3.01 \\
\hline 1.3. Transport systems & 9 & 0.73 \\
\hline 1.4. Air transport & 4 & 0.33 \\
\hline 1.5. Poor connectivity & 100 & 8.14 \\
\hline 1.6. Transport rules, regulations, price & 24 & 1.95 \\
\hline 1.7. Maritime connections & 8 & 0.65 \\
\hline 2. Social/Culture & 356 & 28.97 \\
\hline 2.1. Language & 192 & 15.62 \\
\hline 2.2. Trust & 32 & 2.60 \\
\hline 2.3. Health & 33 & 2.69 \\
\hline 2.4. Education & 51 & 4.15 \\
\hline 2.5. Cultural differences & 37 & 3.01 \\
\hline 2.6. Security & 7 & 0.57 \\
\hline 2.7. Young people & 2 & 0.16 \\
\hline 2.8. Mental barriers & 2 & 0.16 \\
\hline 3. Economy/Technology & 174 & 14.16 \\
\hline 3.1. Economic disparities & 84 & 6.83 \\
\hline 3.2. Fiscal issues & 15 & 1.22 \\
\hline 3.3. Labour market & 49 & 3.99 \\
\hline 3.4. Innovation & 2 & 0.16 \\
\hline 3.5. Entrepreneurship & 3 & 0.24 \\
\hline 3.6. Use of technology & 13 & 1.06 \\
\hline 3.7. Exchange rates & 8 & 0.65 \\
\hline 4. Institutional/Administrative & 399 & 32.47 \\
\hline 4.1. Legal asymmetries (tax-visa-laws) & 166 & 13.51 \\
\hline 4.2. Public authorities involvement & 89 & 7.24 \\
\hline 4.3. CBC structures & 9 & 0.73 \\
\hline 4.4. Governance & 9 & 0.73 \\
\hline 4.5. Information & 19 & 1.55 \\
\hline 4.6. Administrative asymmetries & 81 & 6.59 \\
\hline 4.7. Mobilising civil society & 5 & 0.41 \\
\hline 4.8. EU bureaucracy and budget & 21 & 1.71 \\
\hline 5. Environment & 8 & 0.65 \\
\hline 5.1. National parks collaboration & 6 & 0.49 \\
\hline 5.2. Tourism & 2 & 0.16 \\
\hline 5.3. Heritage protection & 0 & 0.00 \\
\hline Total & 1229 & 100.00 \\
\hline
\end{tabular}

Source: own elaboration based on data from DG REGIO Public Consultation on Border Obstacles in Border Regions. 
Figure 4. Word Map of the DG REGIO inventory of border obstacles - 2017

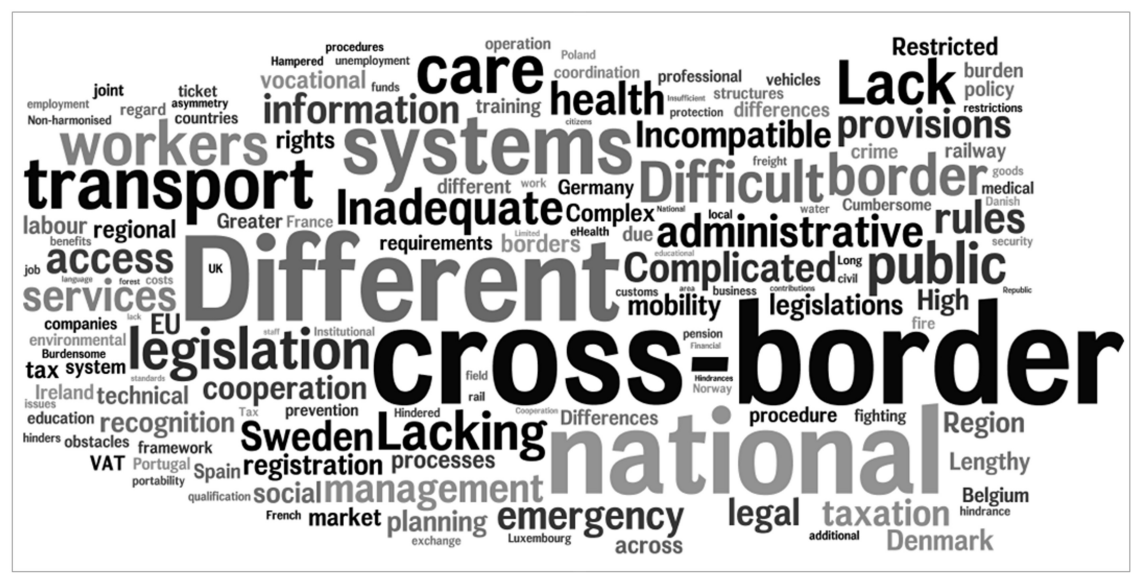

Source: own elaboration.

Figure 5. Location of the border obstacles in a DG REGIO inventory of border obstacles 2017

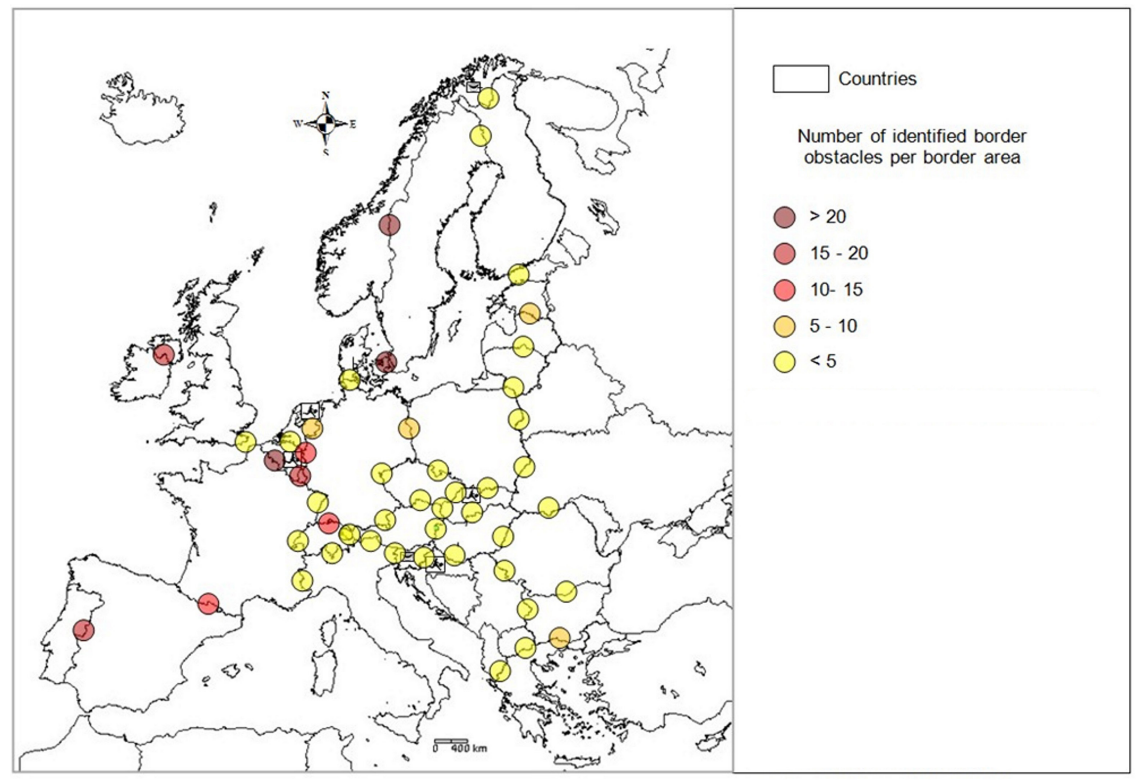

Source: author compilation and cartography based on DG REGIO border obstacles survey. 


\section{Placing the reduction of border obstacles at the core of cross-border cooperation programmes}

At the time of writing these words (September 2017) crucial decisions are being made regarding the future of EU Cohesion Policy and consequently of the ETC post-2020 programmes. As seen in previous sections, ETC, and more specifically EU CBC processes, have gained an increasing and prominent role within EU policies since they were first supported by the INTERREG/ETC programmes in the early 1990s. Moreover, it was possible to testify to the constant metamorphosis of such programmes over the five EU Cohesion Policy programming periods (1989-1993/1994-1999/20002006/2007-2013/2014-2020). More particularly, such INTERREG programmes, although being elevated into one of the major goals of EU Cohesion Policy by 2007, have never gone beyond a relative financial support. Moreover, EU CBC programmes have been mostly seen as an add-on policy instrument to complement other EU regional and cohesion development policies supported by EU funds.

Under this scenario, and based on the vast collection of data related to the persistent border obstacles faced by EU citizens across EU borders, we strongly propose that the post-2020 EU CBC programmes place at the core of their policy strategy intervention the goal of reducing border obstacles. Understandably, the selection of the border barriers to be tackled has to follow a tailor-made approach. In other words, each EU CBC programme should identify the most persistent and important border barriers in a concrete border area in order to define precise policy goals to mitigate them (Medeiros, 2016c; $2017 b$ ). Here, it is expected that more mature EU CBC programmes, located in Northwestern Europe, would place a stronger emphasis on reducing legal and administrative types of barriers, together with language and accessibility (public transport) ones. Conversely, eastern European countries could prioritise the reduction of barriers related to physical accessibility, as well as language and socio-cultural ones (METIS, 2015).

We are well aware that the reduction of many of these obstacles, especially those of a legal-administrative character, cannot be mitigated by the INTERREG/ETC programmes alone. Instead, they require a close intervention from the EU and national authorities to be overcome. Even so, some of these barriers can be reduced by the direct involvement of local and regional authorities at the border areas, as the French and German authorities have successfully achieved in certain domains. ${ }^{2}$ At the same time, the financial package devoted to EU CBC programmes would have to be significantly enlarged if they are to solve prevailing cross-border physical accessibility obstacles.

Indeed, in this particular component, the reduced number of cross-border public transport services is viewed as only one of several border barriers associated with insufficient levels of $\mathrm{CB}$ physical accessibilities, which are

2. Experiences learned in the four DG REGIO border obstacles workshops (2015-2016). 
extensive to the need to: (i) build new, reopen or modernise cross-border physical infrastructures (motorways, high-speed corridors, railways, and maritime and aerial connections) and to (ii) increase the frequency, interoperability and quality of existing cross-border transports systems, and reduce their costs to the public (Medeiros, 2016c). As might be expected, such types of interventions often require large financial packages, as is the case of building or enlarging cross-border roads or railways. Additionally, EU CBC programmes would need to work collaboratively with other EU transport and development policies to succeed in improving cross-border physical connectivity.

At the same time, the post-2020 INTERREG-A programmes could have an improved role in reducing the persistent cultural, social and economic disparities on both sides of border areas. Regarding economic disparities, several concrete actions could be supported in order to reduce existing price ranges of products and services, normalising existing fiscal regimes, wages, and the housing market, and reducing the costs of living on the other side of the border. Again, the reduction of such types of barriers would require the close collaboration of the national authorities on both sides of the border, as economic disparities are not easily solved from one moment to another.

In a different prism, the success of this new rationale for the post-2020 EU $\mathrm{CBC}$ programmes would require the correction of some fundamental causes of the less effective and less efficient implementation of current EU CBC programmes (Figure 6). In more detail, the lack of political will and vision is seen as a major obstacle to the successful implementation of such programmes, as they will affect the design and implementation of adequate $\mathrm{CBC}$ intervention strategies. On the other hand, the lack of financial capability constrains the

Figure 6. Main reason for the lack of improvement of the cross-border cooperation processes (\%)

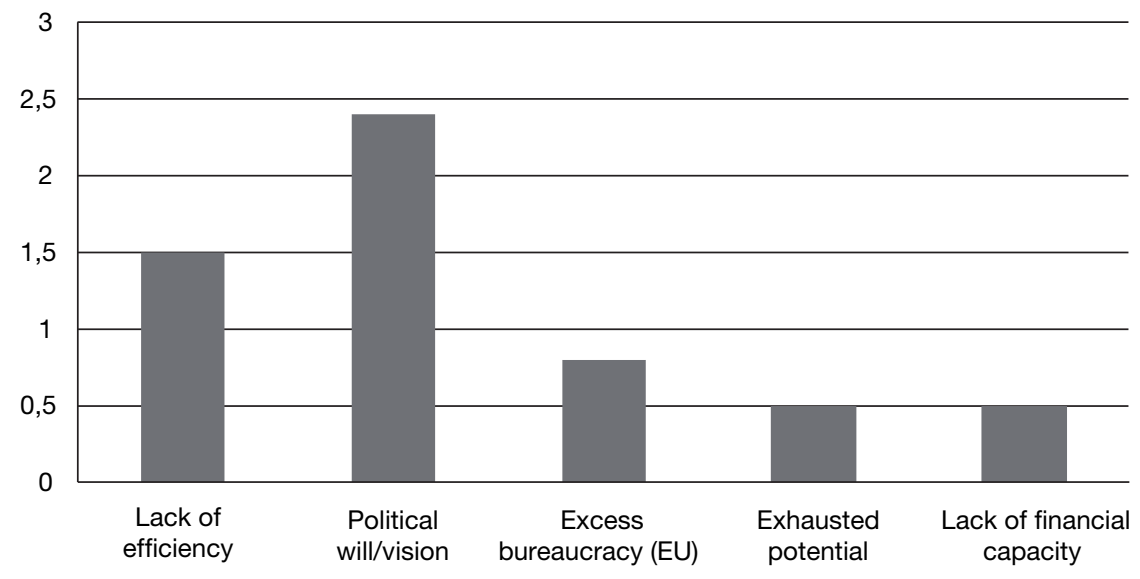

Source: Medeiros (2016c). 
effectiveness of many EU CBC programmes in solving development needs and in reducing concrete border obstacles (Gramillano et al., 2016). Moreover, the excessive bureaucratisation associated with the operationalisation of EU programmes presents a complex panorama to all involved in this process. To complement this picture, other crucial aspects have been noted by the stakeholders involved as major obstacles to a sound and efficient implementation of EU CBC programmes (Medeiros, 2016c):

- The lack of competence or efforts in preparing and implementing $\mathrm{CBC}$ projects

- The increasing difficulties in implementing CBC projects, for instance due to excessive bureaucracy, presence of small and irrelevant projects, and lack of financing

- The lack or low visibility of positive effects of the implementation of $\mathrm{CBC}$ initiatives

- The lack or low political will to promote cross-border collaborations

- The economic context, which is not favourable to increase the level of the CBC process

- The lack or low level of information available to the public

- The emergence/appearance of new problems

- The lack or low participation of younger citizens

- The lack of financial capacity from the other project partner or reduction of available funding

- The excessive physical distance

- The presence of small organisations

- The micro-management of certain universities

- The complicated EU directives and national rules regarding $\mathrm{CBC}$ mobility

At the same time, the spreading out of European Groupings of Territorial Cooperation (Evrard, 2016, 2017) across the European territory could have a pivotal positive impact in reducing legal and administrative types of obstacles. Indeed, as of the end of 2016, 65 EGTCs were already established, five of which were founded in 2016 (CoR, 2016: 8). This could be seen as a positive sign for a wider expansion across the EU territory in the nearby future of such $\mathrm{CBC}$ legal instruments.

On the other hand, the implementation of cross-border planning procedures is still a far cry from being achieved in the EU border region's policy intervention panorama, even though some solid steps have been made towards that goal over the last decade (COMMIN, 2007; Dühr and Nadin, 2007; Faludi, 2006, 2010; Luukkonen and Moilanen, 2012). In this regard, the implementation of cross-border planning strategies could accelerate the process of reducing the barrier effects of all sorts of border obstacles by inducing a sounder and continuous policy strategic intervention in making the most out of the border region's potentials and needs (Medeiros, 2014b). 


\section{INTERREG potentials and limits to reducing border barriers in a nutshell}

As stated on its official site, the EU is a unique economic and political partnership between 28 European countries. Furthermore, it highlights the crucial role of the single or 'internal' market in enabling most goods, services, money and people to move freely. However, the EU has not yet reached the ultimate level of economic integration with a completely unified economic policy, since, for instance, some sectors (in particular services of general interest) are still subject to national laws. If we add to this mix (i) historical factors which forged a patchwork of many European States; (ii) the building process of the EU (marked by several Members States' accession stages), which fostered different levels of territorial cooperation intensity in Europe; (iii) the substantial territorial disparities harboured within the EU borders; and (iv) the fact that the progressive attenuation of border obstacles is often a lengthy process, the persistence of quite a large number of the present border obstacles within the EU territory is justified.

A cursory glance at the responses to the abovementioned border obstacles survey on the awareness of $\mathrm{CBC}$ activities, and the motives for its improvement over time, shows that the implementation of the INTERREG/ETC Programmes is the main direct/indirect factor for such awareness and improvement. Direct, because of the vast number of implemented CBC projects, which involved a vast number of stakeholders. Indirect, because it paved the way for the exponential growth of cross-border entities (Euroregions, Working Communities, EGTCs, Euro-Cities, etc.) and activities in the EU territory. In this regard, local and regional $\mathrm{CB}$ authorities have a prominent role in mitigating all sorts of institutional barriers, y engaging in institutional collaborations of all sorts, both at the local and regional levels. Far less clear is the most adequate level/dimension of public intervention to mitigate such barriers, as it depends on the territorial characteristics of each border region and administrative system of each country involved.

As a consequence, the physical and non-physical connections have improved over time in the EU border regions, with obvious positive consequences for the increasing degree of connectivity between both sides of the border, although at different degrees across the EU territory. Notwithstanding, the increasing permeability of these borders, both physically and administratively, is not only viewed by EU citizens as a direct result of the implementation of the INTERREG/ETC Programmes, but also as an outcome of the implementation of the Schengen Area and the Internal Market, as well as from the direct intervention of cross-border entities and the political will of certain local and regional authorities (Medeiros, 2016c). This goes to say that, in certain border areas, namely where the cross-border cooperation process is far more mature and genuine, cross-border activities go beyond the EU cross-border cooperation financed projects.

Curiously, it is exactly in these EU border areas where the maturity and intensity of the cross-border cooperation process is higher (Northwestern Euro- 
pe) that more EU citizens have identified causes for a certain stagnation of this process in recent years (Medeiros, 2016c). For the sake of clarity, this result can be related with an increasing trend of 'policy dissatisfaction' among EU citizens in areas where the basic needs (physical) to cross the border are far from being satisfied. Also, there is a case for arguing that the implementation of 'immaterial type of projects' is far less visible to the public eye. Moreover, the awareness of the existence of largely bureaucratic (EU) procedures regarding project implementation, and the lack of political will to promote cross-border collaboration, adds to such discontent, which is still relatively low in the overall number of responses provided in the surveys.

But more importantly, in my view, the constant process of reducing physical and administrative barriers in basically all the EU territory has opened an avenue for an increasing level of cross-border mobility, with inherent consequences for the emergence of 'new types of barriers', namely those of a 'legal character'. Indeed, a considerable amount of replies identified a vast number of such types of obstacles, directly or indirectly associated with the need to work or establish a business in a foreign country. In simple terms, such barriers include the existence of different legal regimes on labour markets, diploma or professional recognition, social systems (including health and social security), and transport and communication systems.

As anticipated, the proposed solutions from the replies, basically suggesting the harmonisation of legal regimes on all those areas, is not a prerogative of the INTERREG/ETC Programmes alone, and needs to be solved/mitigated with the intervention of the national authorities in collaboration with the European bodies. This might suggest that $\mathrm{CBC}$ actions could be extended to the national level, and not stick to the border areas. However, such an intention could be seen as a non-desirable interference in the Member-States sovereignty, which might suggest a long and turbulent path ahead to mitigate such types of legal obstacles. Also, for the most part, the differences in administrative systems can only be solved with agreements at the national and EU levels.

Yet does this mean that the identified legal and administrative obstacles are not going to be tackled accordingly? On an optimistic note, it can be stated that some concrete solutions of different kinds and in several domains (labour market, double taxation, social security, transports systems) were already implemented in certain border areas, where the political will and the existence of certain cross-border entities made it possible to reach agreements which favoured all parts. Hence, the challenge here is to expand those solutions to other EU border areas with the necessary contextual adaptation. Here, the role of the ever increasing number of European Groupings of Territorial Cooperation (EGTC) in Europe could act as a facilitator in reducing such types of legal and administrative obstacles.

Moreover, non-legal and administrative barriers, such as transport accessibilities, language, and the presence of economic disparities should be tackled. Also here, the role of the INTERREG/ETC Programmes, as they presently exist, cannot completely solve such types of barriers by themselves. It is true, 
however, that several INTERREG/ETC projects have successfully established permanent cross-border means of transportation across border areas. Be that as it may, one thing seems clear from EU survey responses (Medeiros, 2016c): the insufficient presence of cross-border transportation modes (train, bus, mariti$\mathrm{me}$ ), and the lack of suitability from the existing ones (price, frequency, speed), is still seen as a major obstacle to cross the border on a daily basis or in an occasional situation. Moreover, this scenario applies to basically the entire EU border areas, including in the Northwestern European ones (Benelux, France, and Germany), probably because they have experienced increasing flows of cross-border commuters since the opening of the EU borders.

Regarding the language barrier, there have also been several initiatives, financed under the auspices of the INTERREG/ETC Programmes, to directly (language courses) and indirectly (sport and cultural activities) contribute to mitigating this historical and relevant European barrier. However, there is a need to act at a larger (national) level by including 'the other side of the border speaking language' on the national education systems, right from an early age, and also by promoting bilingual public services along the border areas. All of these proposals, and many others, which include the broadcasting of TV programmes spoken in the neighbouring country's language, are very welcome. However, it goes without saying that the language barrier is, in certain contexts (presence of old and/or non-educated populations), a difficult obstacle to overcome in the short-term.

Finally, the presence of considerable economic disparities on both sides of many EU border areas is, again, somewhat out of the scope of the INTERREG/ETC programmes' main goal, as their financial capacity only covers a drop in the ocean of the border areas territorial development needs. Hence, for the most part, these programmes have been acting as a limited counterweight to the national development trends, which tend to favour capitals and other larger metropolitan areas. Indeed, more often than not, EU border regions are characterised by below national average demographic and socioeconomic dynamics. Even so, some INTERREG/ETC programmes have contributed to stimulating the local/regional economy, especially in areas influenced by medium-sized towns. However, the correction of economic disparities along the border areas requires, once again, a higher level (national and EU) of intervention.

To conclude this analysis, one can infer that the $\mathrm{CBC}$ process in the $\mathrm{EU}$ is very much alive and dynamic, and that the INTERREG/ETC programmes are vital to place it on the political agenda at all territorial levels (from the local to the EU). Furthermore, and despite the different levels of CBC maturity and intensity across the EU border areas, the fact remains that, in all situations, the challenges ahead to reduce the existing border obstacles in these areas require a constant survey and policy adaptation to new types of barriers, namely of a legal and administrative character.

In this context, future generations of the INTERREG/ETC programmes should, in my view, take stock of the information provided by 'EU surveys on 
persisting border barriers', in order to design tailor-made and focused policy interventions, which give a preferential focus to the reduction of the most prevailing barriers in the border area covered by such programmes. In parallel, each Member State, together with European Commission services, should continue this effort of updating the collected survey information on the existing EU 'border obstacles' on a yearly basis in order to constantly adapt the policy interventions based on the new inputs.

\section{Conclusion}

The Association of European Border Regions often refers to European borders as 'scars of history'. We do not personally like that denomination. Instead, we tend to look at the presence of administrative borders, which divide sovereign countries, as natural consequences of exerting territoriality processes, which is much associated with the human species nature, both as an individual and as a group of individuals (society). The main problem here is the fact that the creation of distinct national states leads to the forging of divergent sets of laws, regulations, rules, procedures and so on. With time (read decades and centuries), such differences tend to crystallise, thus creating enormous constraints for those who need to cross European borders, especially if they do it on a regular basis (cross-border commuters).

It is true that since the implementation of the INTERREG/ETC programmes, positive advances have been made to reduce all sorts of border barriers in basically all EU border areas despite the fact that their main priorities have usually shifted away from this concrete policy goal. Instead, these programmes have been mostly used as an additional financial tool to promote regional development of EU border regions with a view to dealing with the implementation of the Single Market in an initial phase. More recently, however, INTERREG/ ETC programmes have been 'obliged' to follow EU-defined political thematic objectives, thus restraining even more its fundamental role as a pivotal policy tool for reducing border obstacles.

Under this panorama, we propose a policy priority shift for the post-2020 INTERREG/ETC programmes. In essence, we defend that such programmes should be used, first and foremost, to help mitigate persisting EU border barriers. To support this claim, the recent collection of data related with perceived (Eurobarometer and DG REGIO border obstacles survey) and measurable border obstacles in the EU paints a clear picture of persistent border barriers of all sorts across the EU borders. These border obstacles are especially strong in three domains: (i) legal and administrative; (ii) language; and (iii) physical accessibilities. Indeed, even in border areas between 'old EU Member States', the presence of such types of barriers presents a formidable obstacle to cross-border commuters. More particularly, legal and administrative issues related with taxation, social security, access to employment, qualifications recognition and access to health care top the list of the main obstacles faced by EU citizens. Furthermore, the lack or reduced number of 
available cross-border public transport, as well as the inadequacy of many cross-border physical connections (road and rail), add to the list of the most relevant EU border obstacles faced by cross-border commuters, together with language related barriers.

We are well aware, though, that the INTERREG/ETC programmes cannot solve by themselves all the EU border obstacles mentioned above. Indeed, the mitigation of most legal and administrative types of obstacles requires a collaborative intervention between all territorial administrative levels. In addition, the improvement of cross-border physical connections demands adequate financial muscle, which is not always the case of the abovementioned programmes. As such, alongside the strategic shift towards the reduction of persistent barriers, we propose the reinforcement of the financial package for the post-2020 INTERREG/ETC programmes. If so, cross-border commuters could experience in the medium and longer term a closer experience to the ultimate goal of a Europe without borders, which is still far from being a reality.

\section{Acknowledgements}

The author thanks the editor and two anonymous referees for their useful suggestions and comments.

\section{Bibliographical references}

AEBR (ed.) (2008). Cooperation between European border regions. Review and Perspectives. Baden-Baden: Nomos.

BARCA, Fabrizio (2009). An agenda for a reformed cohesion policy. A placed-based approach to meeting European Union challenges and expectations. Independent Report prepared at the request of Danuta Hübner. Brussels: Commissioner for Regional Policy.

BRENNER, Neil (2000). "Building Euro-regions, Locational politics and the political geography of neoliberalism in post-unification Germany". European Urban and Regional Studies, 7 (4), 319-345. $<$ http://dx.doi.org/10.1177/096977640000700403>

Buch, Tanja; SCHMidT, Torben Dall and NiebuHR, Annekatrin (2009). "Cross-border commuting in the Danish-German border region. Integration, institutions and cross-border interaction". Journal of Borderlands Studies, 24 (2), 38-54. <http://dx.doi.org/10.1080/08865655.2009.9695726>

Chilla, Tobias; EvRARD, Estelle and SchUlz, Christian (2012). "On the Territoriality of Cross-Border Cooperation: "Institutional Mapping" in a Multi-Level Context". European Planning Studies, 20 (6), 961-980. $<$ http://dx.doi.org/10.1080/09654313.2012.673563>

COMMIN (2007). Baltic Sea Region INTERREG III B project "Promoting Spatial Development by Creating COMmon MINdscapes - COMMIN, National Glossary GERMANY - Central German spatial development and planning terms, p. 260.

CoR (2016). EGTC monitoring report 2016 and impacts of Schengen area crisis on the work of EGTCs, Brussels: Committee of the Regions. 
Decoville, Antoine; Durand, Frederic; Sohn, Christophe and Walther, Olivier (2013). "Comparing Cross-border Metropolitan Integration in Europe: Towards a Functional Typology”. Journal of Borderlands Studies, 28 (2), 221-237. <http://dx.doi.org/10.1080/08865655.2013.854654>

DÜHR, Stephanie and NADIN, Vincent (2007). "Europeanization through transnational territorial cooperation? The case of INTERREG IIIB North-West Europe". Planning Practice \& Research, 22 (3), 373-394. <http://dx.doi.org/10.1080/02697450701666738>

EC (1990a) Interreg - Breaking through borders, Community initiatives, InfoBackground B-501-90. Brussels: Directorate General for Regional Policy Commission of the European Communities.

- (1990b). INTERREG - Community Initiatives. Brussels: Directorate General for Regional Policy Commission of the European Communities.

- (1999). European spatial development perspective: Towards a balanced and sustainable development of the territory of the European Union. Luxembourg: Office for Official Publications of the European Communities.

- (2007). The European Territorial Cooperation Objective, Panorama, INFOREGIO, no 24, December 2007. Brussels: European Union Regional Policy, European Commission.

- (2008). Green Paper on Territorial Cohesion - turning territorial diversity into strength. Brussels: European Commission.

- (2010). INTERREG III Community Initiative (2000-2006) Ex-Post Evaluation (No. 2008. CE.16.0.AT.016) Final Report. Brussels: European Union Cohesion Policy, PANTEIA, European Commission.

- (2011). European territorial cooperation - Building bridges between people. September 2011. Brussels: European Commission.

- (2014). Sixth Report on Economic, Social and Territorial Cohesion. Investment for jobs and growth: Promoting development and good governance in EU regions and cities. Brussels: European Commission.

- (2016). Overcoming obstacles in border regions, Summary Report on the online public consultation 21 September - 21 December 2015. Brussels: DirectorateGeneral for Regional and Urban Policy, European Commission.

- (2017a). INTERREG III Programmes. <http://europa.eu.int/comm/regional_policy/interreg3/inte2/summary_en.htm > [Consulted 26 ${ }^{\text {th }}$ January 2017]

- (2017b). LEADER Programmes. <http://ec.europa.eu/agriculture/rur/leader2/ruralen/euro/p2-2.htm $>$ [Consulted 26 ${ }^{\text {th }}$ January 2017]

- (2017c). INTERREG IV Programmes. <http://ec.europa.eu/regional_policy/en/ policy/cooperation/european-territorial/cross-border/2007-2013/> [Consulted $26^{\text {th }}$ January 2017]

- (2017d). INTERREG VI Programmes. <http://ec.europa.eu/regional_policy/en/policy/ cooperation/european-territorial/cross-border/\#3/> [Consulted 26 ${ }^{\text {th }}$ January 2017]

EP (1996). Cross-border and Inter-regional cooperation in the European Union. Executive Summary, Conclusions and Recommendations, Directorate General for Research. Working Papers, Regional Policy Series, W-19. Luxembourg: European parliament.

ESPON (2007). Cross-Border Cooperation. Cross-Thematic Study of INTERREG and ESPON activities. Luxembourg: INTERACT and ESPON.

ESPON ATLAS (2014). ESPON ATLAS Mapping European Territorial Structures and Dynamics, November 2014. Luxembourg: ESPON. 
EVrard, Estelle (2016). “The European Grouping of Territorial Cooperation (EGTC): Towards a Supraregional Scale of Governance in the Greater Region SaarLorLux?”. Geopolitics, 21 (3), 513-537. <http://dx.doi.org/10.1080/14650045.2015.1104667>

- (2017). "Encapsulating the significance of the EGTC for territorial cooperation: a literature review and tentative research agenda". In: MEDEIROS, Eduardo (ed.). Uncovering the Territorial Dimension of European Union Cohesion Policy. London: Routledge, 127-144.

FALUDI, Andreas (2006). "From European spatial development to territorial cohesion policy”. Regional Studies, 40 (6), 667-678. <http://dx.doi.org/10.1080/00343400600868937>

- (2010). Cohesion, Coherence, Cooperation: European Spatial Planning Coming of Age? New York: Routledge.

GAUBERT, Nicolas and YanN, Richard (2010). "European Cohesion Policy and Territorial Cooperation with Neighbouring Countries: Towards Deeper Coordination?". European Journal of Spatial Development, Refereed Articles, October 2010, No. 41.

Gramillano, Andrea; Levarlet, François; Nilsson, Henrik; Camagni, Roberto; Capello, Roberta; Caragliu, Andrea; Fratesi, Ugo and LindberG, Gunnar (2016). Collecting solid evidence to assess the needs to be addressed by Interreg crossborder cooperation programmes. Brussels: Directorate General for Regional and Urban Policy, European Commission.

HarguindéGuY, Jean-Baptiste (2007). "Cross-border Policy in Europe: Implementing INTERREG III-A, France-Spain”. Regional \& Federal Studies, 17 (3), 317-334. <http://dx.doi.org/10.1080/13597560701543717>

Huber, Peter and Nowotny, Klaus (2013). "Moving across Borders: Who is willing to migrate or to mommute?". Regional Studies, 47 (9), 1462-1481.

Johnson, Corey (2009). "Cross-Border Regions and Territorial Restructuring in Central Europe: Room for More Transboundary Space”. European Urban and Regional Studies, 16 (2), 177-191.

<http://dx.doi.org/10.1177/0969776409102190>

LAWRENCE, Roger (2011). "Deriving collaborative aims and outcomes: A case-study of cross-border cooperation in Central and Eastern Europe". Evaluation, 17 (4), 365-382. <http://dx.doi.org/10.1177/1356389011421927>

LÓpez, Elena; Monzón, Andrés; OrTega, Emilio and Quintana, Santiago Mancebo (2009). "Assessment of Cross-Border Spillover Effects of National Transport Infrastructure Plans: An Accessibility Approach”. Transport Reviews, 29 (4), 515536. <http://dx.doi.org/10.1080/01441640802627974>

LRDP (2003). Ex-post evaluation of the INTERREG II Community Initiative (199499). Technical Report 1, Contract No: 2002.CE.16.0.AT.138, LRDP LTD, London.

Lundén, Thomas (2004). On the boundary. About humans at the end of territory. Huddinge: Södertörns Högskola.

LuUKKONEN, Juho and MoILANEN, Helka (2012). "Territoriality in the strategies and practices of the territorial cohesion policy of the European Union: Territorial challenges in implementing 'soft planning'”. European Planning Studies, 20 (3), 481-500. <http://dx.doi.org/ 10.1080/09654313.2012.651806> 
MATAS, Anna; RaYMOnD, Josep-Lluis and RoIG, Josep-Lluis (2015). "Wages and Accessibility: The Impact of Transport Infrastructure". Regional Studies, 49 (7), 1236-1254. <http://dx.doi.org/10.1080/00343404.2013.827336>

Medeiros, Eduardo (2010). "Old vs Recent Cross-Border Cooperation: PortugalSpain and Sweden-Norway". AREA, 42 (4), 434-443. <http://dx.doi.org/10.1111/j.1475-4762.2010.00940.x>

- (2011). "(Re)defining the Euroregion concept". European Planning Studies, 19 (1), 141-158.

<http://dx.doi.org/10.1080/09654313.2011.531920>

- (2013). "Euro-Meso-Macro: The new regions in Iberian and European Space". Regional Studies, 47 (8), 249-1266. $<$ https://doi.org/10.1080/00343404.2011.602336>

- (2014a). "Barrier Effect and Cross-Border Cooperation: Sweden-Norway INTERREG.A Territorial Effects". Finisterra, XLIX (98), 87-100. <http://dx.doi.org/10.18055/Finis4198>

- (2014b). "Is there a new 'trust' in Inner Scandinavia, Evidence from Cross-Border Planning and Governance”. Geografiska Annaler. Series B, Human Geography, 96 (4), 363-386. <http://dx.doi.org/10.1111/geob.12057>

- (2014c). "Territorial cohesion trends in Inner Scandinavia: the role of cross-border cooperation (INTERREG-A 1994-2010)”. Norsk Geografisk Tidsskrift, 68 (5), 310-317.

<http://dx.doi.org/10.1080/00291951.2014.960949>

- (2014d). "From Cross-Border Cooperation to Cross-Border Planning", Open Days, University Master Class, Book of Papers: 207-213.

- (2015). "Territorial Impact Assessment and Cross-Border Cooperation". Regional Studies, Regional Science, 2 (1), 95-115.

<http://dx.doi.org/10.1080/21681376.2014.999108>

- (2016a). "Territorial Cohesion: A European Concept". European Journal of Spatial Development, 60. Available from: <http://www.nordregio.se/Global/EJSD/Refereed articles/refereed60.pdf>.

- (2016b) "Is there a rise of the territorial dimension in EU Cohesion policy". Finisterra, 103, 89-113. $<$ http://dx.doi.org/10.18055/Finis7940>

- (2016c). Analysis of the results of DG REGIO's online public consultation on Overcoming Obstacles in Border Regions. Brussels: European Commission. Available from: $<$ https://www.dropbox.com/s/je3q5rtz0jiqk67/REP_Border_Obstacles_DGREGIO.pdf?dl=0>.

- (2017a). "Cross-border cooperation in inner Scandinavia: A territorial impact assessment”. Environmental Impact Assessment Review, 62 (2017), 147-157. <http://dx.doi.org/ 10.1016/j.eiar.2016.09.003>

- (2017b). "From smart growth to European spatial planning: a new paradigm for EU Cohesion Policy post-2020”. European Planning Studies, 25 (10), 1856-1875. <http://dx.doi.org/10.1080/09654313.2017.1337729>

METIS (2015). Easing legal and administrative obstacles in EU border regions. Vienna: METIS, CASE, Panteia, AEIDL, ICF, Inception Report.

Molle, Willem (2007). European Cohesion Policy. Abingdon: Routledge.

MOT (2006). Les transports transfrontaliers de voyageurs. Les Cahiers de la Mot, no 6. Paris: Mission Opérationnelle Transfrontalière. 
- (2015). Cross-border economic development. Introduction and project factsheets. Paris: Mission Opérationnelle Transfrontalière.

Newman, D. (2006). "Borders and Bordering: Towards an Interdisciplinary Dialogue”. European Journal of Social Theory, 9 (2), 171-185. <http://dx.doi.org/10.1177/1368431006063331>

PERKMANN, Markus (1999). "Building governance institutions across European borders". Regional Studies, 33 (7), 657-667. <http://dx.doi.org/10.1080/00343409950078693>

- (2003). "Cross-border regions in Europe - significance and drivers of regional cross-border co-operation". European and Urban and Regional Studies, 10 (2), 153-171. <http://dx.doi.org/10.1177/0969776403010002004>

- (2007a). "Construction of new territorial scales: A framework and case study of the EUREGIO cross-border region”. Regional Studies, 41 (2), 253-266. <http://dx.doi.org/10.1080/00343400600990517>

- (2007b). "Policy entrepreneurship and multilevel governance: A comparative study of European cross-border regions". Environment and Planning C: Government and Policy, 25 (6), 861-879. <http://dx.doi.org/10.1068/c60m>

SMAllbONe, David and Welter, Friederike (2012). "Cross-border entrepreneurship". Entrepreneurship \& Regional Development, 24 (3-4), 95-104. <http://dx.doi.org/10.1080/08985626.2012.670907>

TERritorial AgEnda (2007). Territorial agenda of the European Union: Towards a more competitive and sustainable Europe of diverse regions. Retrieved from <http:// ec.europa.eu/regional_policy/sources/policy/what/territorial-cohesion/territorial_ agenda_leipzig2007.pdf>

Vickerman, Roger; Spiekermann, Klaus and Wegener, Michael (1999). "Accessibility and Economic Development in Europe". Regional Studies, 33 (1), 1-15 <http://dx.doi.org/10.1080/00343409950118878>

Wassemberg, Birte; Reitel, Bernard and Peyrony, Jean (2015). Territorial Cooperation in Europe. A historical perspective. Brussels: Regional and Urban Policy, European Commission. 